EGU2020-5569

https://doi.org/10.5194/egusphere-egu2020-5569

EGU General Assembly 2020

(c) Author(s) 2021. This work is distributed under

the Creative Commons Attribution 4.0 License.

\title{
Regional structural control on the Mont-Dore plio-quaternary volcanism (France)
}

Camille Daffos, Laurent Arbaret, Jean-Louis Bourdier, and Charles Gumiaux Institut des Sciences de la Terre d'Orléans (ISTO), Université d'Orléans, CNRS, BRGM, UMR 7327, Orléans, France (camille.daffos@univ-orleans.fr)

The relationship between volcanic and tectonic activity is well known. The volcanic activity strongly depend on the geodynamic context. This relationship is well highlight for systems like monogenic, mostly basaltic, volcanic fields (Cebrià and al, 2011). However, for complex, polygenetic, volcanic systems, this relationship remains very poorly constrained. The Mont-Dore Plio-Quaternary volcanic complex (4.7 to $0.3 \mathrm{My}$ ) is one of such polygenetic volcanic fields. This alkaline volcanism is located in the French Central massif. We define three eruptive cycles: The Bourboule caldera (3.3 to $2.2 \mathrm{My}$ ); the Aiguiller complex in the north (2.5 to $1.5 \mathrm{My}$ ) and the Sancy stratovolcano with the Adventif massif in the south-east (1.5 to $0.3 \mathrm{My}$ ).

Analysis coupling Coulomb fractures and faults kinematics in the variscan basement and directions of volcanic centers alignments analysed by Hough transform method highlight a strong influence of the basement fracturing on volcanism distribution. The late-variscan N20 and N160 main fracture directions were reactivated as normal faults during the oligocene E-W rifting. This fault system continued to act from the Miocene to the present day uplift, associated with new N20, flat-lying, coulomb fractures relevant with a present-day NW-SE compressional regional stress field. During the La Bourboule caldera activity, new N60 and N130 fractures were activated, some acting as normal faults. The contemporaneous vertical dykes injected the volcanic deposits mainly along the N60 direction. This suggest that this local N60-N130 brittle network were formed during the successive collapses that formed the La Bourboule caldera. In the Aiguiller massif, the brittle network is mainly composed of N-S and E-W directions. The E-W direction include normal faults that structure the north flank of the Mont-Dore horst. N-S trending volcanic dykes and alignments of monogenic volcanic events along the E-W directions point out a strong control of the fracturation of the granitic horst on the volcanic activity in the Aiguiller massif. The Sancy volcano and the Massif Adventif are marked by dykes and alignment of volcanic events that mostly trend N20. Only few dykes measured in the central area of the Sancy stratovolcano exhibit dispersed, radial, directions suggesting a local contribution of the volcanic edifice on the superficial stress field.

This study point out the strong control by the regional tectonic stress field on the activity of the Mont-Dore Plio-Quaternary volcanic complex. Alignment of monogenic edifices and dykes along the associated N20/N160 regional brittle directions is also evidenced in the northern monogenic 
field of the Chaine des Puys (Boivin et al. 2017). In contrast, larger volcanic activity such as caldera collapses or the building of a strato-volcano perturb the regional stress field creating a specific superficial stress field with its own fracture and faults networks.

Boivin et al. 2017. Volcanologie de la Chaîne des Puys. $6^{\mathrm{e}}$ édition. Carte 1/25.000, 120x90 ; notice $199 \mathrm{p.}$

Cebrià, J.M., Martin-Escorza, C., Lopez-Ruiz, J., Moran-Zenteno, D.J., and Martiny, B.M. Numerical recognition of alignments in monogenetic volcanic areas: Exemples from the MichoacanGuanajuato Volcanic Field in Mexico and Calatrava in Spain. Journal of Volcanology and Geothermal Research. 2011,201, 73-82. 